\title{
Selection of Black Bengal Buck Based on Some Reproductive Performance of Their Progeny at Semi-Intensive Rearing System
}

\author{
M. N. Haque ${ }^{1}$, S. S. Husain ${ }^{2}$, M. A. M. Y. Khandoker², M. M. Mia ${ }^{1} \&$ A. S. Apu ${ }^{2}$ \\ ${ }^{1}$ Department of Genetics and Animal Breeding, Sylhet Agricultural University, Sylhet, Bangladesh \\ ${ }^{2}$ Department of Animal Breeding and Genetics, Bangladesh Agricultural university, Mymensingh, Bangladesh \\ Correspondence: M. N. Haque, Department of Genetics and Animal Breeding, Sylhet Agricultural University, \\ Sylhet, Bangladesh. E-mail: drnayandvm11@gmail.com
}

Received: May 10, 2013 Accepted: June 3, 2013 Online Published: July 15, 2013

doi:10.5539/jas.v5n8p142 URL: http://dx.doi.org/10.5539/jas.v5n8p142

\begin{abstract}
The objective of this study was to select Black Bengal Buck Based on some reproductive performance of their progeny. The least-squares means for overall reproductive performances of age of first kidding (AFK), weight at first kidding (WFK), gestation length (GL), kidding interval (KI), post-partum heat (PPT), litter size at birth (LS) and litter weight at birth were 465.6 days, $13.22 \mathrm{~kg}, 145.34$ days, 302.5 days, 123.84 days, 1.61 and $1.66 \mathrm{~kg}$, respectively. The effect of flock and generation were significant $(\mathrm{p}<0.05)$ for AFK, WFK, KI, PPT, LS and LWB. The effect of parity of doe was significant $(p<0.01)$ for LSB and LWB. The effect of season was significant $(p<0.05)$ for KI, PPT and LWB. The heritability value for these traits was ranges from 0.17 to 0.24 and predicted breeding value from -0.003 to 0.445 . According to the genetic worth of the buck the highest breeding value of reproductive traits were found in the progeny of Buck No. 32, followed by Buck No. 52, 54, 81 and 87. This progeny tested bucks may be used for the improvement of the reproductive potentials of Black Bengal goat through Artificial Insemination (A.I). The lowest breeding value of reproductive traits was found from the progeny of Buck No. 3 followed by Buck No. 11. The low estimates of heritability obtained for reproductive traits indicated that selection based on the doe's own performance may result in slow genetic improvement therefore; the progeny testing program will be beneficial to the farmers and fulfill their need by supplying superior sires of high genetic merit.
\end{abstract}

Keywords: black bengal buck, reproduction, progeny, breeding value, selection

\section{Introduction}

Reproductive efficiency is always considered to be the most vital factor ensuring increase in productivity to a certain environmental condition (Hossain et al., 2004). Increased production efficiency can be obtained from goats since they have a high reproductive efficiency with the potential for increased litter size and shorter generation interval and they have a relatively higher fertility rate in comparison to other farm animals (Williamson \& Paney, 1978). Reproductive performance of goats is a major determinant of productivity and economic viability of commercial goat farms. The goats' reproductive performance is an indicator of their adaptation to the adverse conditions. Reproduction is a complex composite trait influenced by many components including puberty, estrus, ovulation, fertilization, embryo implantation, pregnancy, parturition, lactation, and mothering ability. Reproductive efficiency in female goats is determined by many different processes (Shelton, 1978). These processes include, for example, the length of the breeding season, cyclic activity, ovulation rate, fertilization rate, the post-partum anoestrous period and the growth and viability of the offspring.

Selective breeding using superior buck expected to improve the productive efficiency of Black Bengal goats without much alteration in the prevailing production system. Selective breeding was an important tool for conservation of the well adapted genetic resources and thus avoid fore coming extinction of the breed (Dhara et al., 2008). Selection improves the reproduction and growth for conserving the characteristics to adopt tropical goats to their environment and reduce under harsh environmental conditions and have good fitness traits (Wilson, 1989).

Reproductive traits are economically important characters which could be improved by selection of local breeds (Mourad, 1993). The number of individuals born per parturition makes a much greater contribution to the total weight of individuals weaned than the growth rate of individuals (Bradford, 1985). Thus reproductive rate is an 
economically important trait in small ruminant production enterprises. Both biological and economic traits are improved with high levels of flock reproduction. Improvement of reproductive traits can have more economic impact than improving growth rate (Dickerson, 1978). Reproduction is a major contributing factor to efficiency of meat production and makes an important contribution by influencing the number of surplus animals which may be utilized for meat and contributing to current and future production through culling (Song, 2003). One of the most favorable attributes of the Black Bengal goat as a meat producing animal is its high rate of reproduction and the fact that it has an extended breeding, especially as reproduction is a major contributing factor to the efficiency of meat production.

The level of reproductive performance of goats is dependent on genetic and environmental factors, but this performance is particularly sensitive to the latter (Devendra \& Burns, 1970; Riera, 1982; Song et al., 2006). Although this breed has an excellent ability to accommodate and adapt to fluctuation in environment, this often involves some degree of reproductive failure (Devendra \& Burns, 1983). The goat is the most prolific of all domestic ruminants under tropical and sub-tropical conditions and certain breeds are able to breed throughout the year (Devendra \& Burns, 1983), while other breeds like, for example, the Angora have a restricted breeding season (Shelton, 1978; Van der Westhuysen, 1980).

There has been a growing interest and necessity for more knowledge concerning the reproductive characteristics of farm animals, with the widespread application of artificial insemination in domestic animals. The genetic effect on each component of reproduction varies (Safari et al., 2005). Within a production or management system, the phenotypic variation of a composite trait is influenced by the level of variability among its component traits and their interactions (Snowder, 2008). Although component traits of reproduction are under the influence of many genes, a limited number of major genes associated with separate components of reproduction have been reported (Piper \& Bindon, 1982; Bradford et al., 1986). Expressions of the genetic effects on reproduction are affected by numerous environmental factors such as season, climatic conditions, management, health, nutrition, breeding ratio, age and weight of doe, and libido of buck and fertility. Because genetic and environmental factors interact, genetic improvement of reproduction is very complicated (Snowder, 2007).

Flock reproductive rate also affects selection intensity and consequently the rate of genetic improvement in all traits under selection (Dickerson, 1978). Compared with improved genotype, except in terms of litter size (Wilson, 1989), the reproductive rate of small ruminants in Africa is high. However, the high reproductive potential is not usually contributing to increase production due to reproductive wastage (Mukasa-Mugerwa et al., 1992). Reproductive efficiency can be measured and expressed as the kidding rate, weaning rate, kidding interval, live weight of kids born or weaned and the length of the reproductive cycle (Greyling, 1988, 2000).

Genetic improvement in reproduction and growth traits is major goals in livestock breeding. Efficiency of livestock production is controlled by reproduction, female production and growth of offspring and concluded that improvements in reproduction were particularly likely to increase efficiency of livestock production. Development of effective genetic evaluation and improvement programmed requires knowledge of the genetic parameters for the economically important traits (Safari et al., 2005). Total weight of lamb weaned per ewe exposed to breeding provides an overall indication of ewe fertility, prolificacy, maternal performance and rearing ability as well as lamb survival and growth (Falconer \& Mackay, 1996).

Reproductive efficiency is one of the important pre-conditions for increasing production potential in any given environment. In order to evaluate the productive ability of goats, prolificacy and birth weight are considered the most important and economic criteria (Morand-Fehr, 1981). The number of young born alive per kidding is an important factor in increasing productivity as it contributes more to the total weight weaned per dam than the growth rate of the kid (Bradford, 1985). It is evident that the short generation interval, non seasonality and multiple births of goat make it possible to increase production more rapidly than other ruminants in the tropics.

Reproductive merit is important consideration when evaluating the strength and weakness of new breeds in particular production environments. Breed of dam affects kid performance among various sire breeds. Reproduction fitness trait strongly influenced by environmental origins and associated selection pressures.

Thus improving the reproductive management could lead to a significant increase in productivity. The objective of the current study was (1) to evaluate the reproductive performance of Black Bengal goat and identify important factors which may influence selection of buck; and (2) to estimate variance components, heritability and breeding value for selection and ranking Black Bengal buck at different condition. 


\section{Materials and Methods}

\subsection{Location}

The study was conducted in three different locations of the country under the Department of Animal Breeding and Genetics, Bangladesh Agricultural University, Mymensingh from April 2007 to June 2011. The regions were Tangail (Modhupur flock), Nilphamari (Dimla flock) and the Bangladesh Agricultural University (BAU) flock at the Artificial Insemination Centre.

\subsection{Animals and Management}

A total of 251 Black Bengal does and 22 Black Bengal bucks were used as parents for reproductive performance. Black Bengal Breeding does were reared in semi-intensive rearing system at different flock. Under the Mellonite Central Committee (MCC) and Monga Mitigation Project (MMP) selected farmers were distributed does in Madhupur flock and Dimla flock. These flocks were selected on the basis of the concentration of goat population and easiness of communication facilities and interest of the BAU and NGO workers. The farmers of each area were informed intensively for about a week for acquainting them about the various aspects and problems associated with the prevailing goat production systems and appropriate preventive measures. The objective of this joined work was to popularize AI technique and to evaluate buck effect in goat in village condition.

The animals were housed separate houses made for them or adjacent to the living rooms. Animals were grazed and supplied green grasses and concentrate feed and clinically examined regarding the health of their external genitalia Immediate veterinary assistance was given as and when necessary. The health care package includes dipping, deworming and routine vaccination against Peste des Petits Ruminants (PPR). The treatment facilities were made available to the farmers on an emergency basis were advised regarding the preventive measures against different diseases. The signs of heat were observed by the farmers as well as by Field Assistants in the morning and evening. Does in heat were inseminated with frozen semen of the Black Bengal bucks maintained at BAU flock with the help of Field Assistant.

All the breeding animal and progeny were identified with neckband tags in order to maintain their individual identity and pedigree. The identities of newborns and their parents, date of insemination, date of kidding, sex of kid, litter size and parity of does were recorded. For each individual under study a record sheet with full details of each parameter along with pedigree information were maintained. New-born kids were allowed to suckle their does and were left with them up to 3-month of age. Kids were weaned at 3-month of age. Body weight $(\mathrm{kg})$ was recorded in the morning before the animals were fed. Black Bengal Breeding bucks were reared at the Artificial Insemination (AI) Center under the Department of Animal Breeding and Genetics, Bangladesh Agricultural University (BAU), Mymensingh. Bucks were reared intensively and were housed in individual pens of one square meter in galvanized iron sheet shed with a wooden slatted floor raised above the ground level. The house was provided with necessary arrangements for feeding and watering with provision of sufficient access to fresh air. The selection of buck was made on the basis of their physical character (Growth, biometry and semen characteristics) at the beginning of the study. A member of the thin family was preferred over single or triplet. Afterwards, the bucks which gave better progeny performance were kept for further breeding program and the inferior bucks determined by progeny performance were replaced by superior bucks selected on the basis of same characters described earlier. This process was continued.

The bucks were kept under zero grazing management and stall fed twice daily on a diet consisting of Napier, German and/or Maize fodder ad libitum. The feed was supplemented with the commercial concentrate in pellet form in the morning and again in the afternoon at the rate of $400 \mathrm{~g} / \mathrm{buck} / \mathrm{day}$. They were allowed for exercise 1 to 2 hours daily. The breeding bucks were also supplied with germinated gram ( $20 \mathrm{~g} /$ buck/day). The weights were taken using a platform balance with an accuracy of $10 \mathrm{~g}$.

\subsection{Traits Analysed}

The following parameters were investigated: age at 1st kidding of dams (days), weight at 1st kidding (kg) of dams, Gestation length (days) for each kidding, litter size at birth, Litter weight at birth, post-partum heat period (days), kidding interval (days).

\subsection{Statistical Analyses}

The significance of fixed effects (nongenetic factors) for all the traits were tested by least-squares analyses of variance using the general linear model (GLM) procedure of the Statistical Analysis System (SAS, 1998) according to the following linear model:

Statistical model for reproduction trait: 


$$
\text { Yijklm }=\mu+\mathrm{R}_{\mathrm{i}}+\mathrm{G}_{\mathrm{j}}+\mathrm{P}_{\mathrm{m}}+\mathrm{Sea}_{\mathrm{n}}+\text { Eijmn }
$$

Where,Yijklmn is the dependent variable (individual animal record for the trait), $\mu$ is the overall mean, $R_{i}$ is the effect of flock: ( $i=1-3), G_{j}$ is the effect of generation: $(j=1-3), P_{m}$ is the effect of parity of dam: $(m=1-3)$, Sea $a_{n}$ is the effect of season of birth: ( $\mathrm{n}=1-3$ The year was divided into three seasons; $1=$ winter (from November to February), $2=$ summer (from March to June) and 3=rainy (from July to October).

Eijmn is the residual error.

\subsection{Ranking of Bucks}

Deep frozen semen from 22 Black Bengal breeding bucks was used as sire line in the present study. In this study, bucks were ranked according to the predicted breeding values calculated using their progeny reproductive performance. As is known, animal breeders always try to select the best bucks for breeding with the aim that their progeny will be better than the population average.

Breeding value of animals for the traits was estimated using Best Linear Unbiased Prediction (BLUP) methodology. The BLUP in turn was carried out by computer program prediction and estimation (PEST) proposed by Groeneveld et al. (2003) using a single trait animal model.

\section{Results and Discussion}

The overall female reproductive traits of Black Bengal goats are provided in Table 1. The overall mean age at first kidding (days), weight at first kidding ( $\mathrm{kg}$ ), gestation length (days), litter size at birth, litter weight at birth $(\mathrm{kg})$, post-partum heat (days) and kidding interval (days) were $465.6 \pm 12.45,13.22 \pm 0.24,145.34 \pm 0.32,1.61 \pm 0.02$, $1.66 \pm 0.04,123.84 \pm 1.85$, and $302.5 \pm 4.55$, respectively. Highest coefficient of variation was observed for post-partum heat (days) $(42.97 \%)$, there after for litter weight at birth $(35.64 \%)$ and the lowest for gestation length (2.90\%). These result was comparable with the figure reported by Hossain et al. (2004) of 401.5 days for Black Bengal goat, Ribeiro et al. (2000) of 402.28 days for Saanen goat, Kataktalware et al. (2004) of 457.71 days for Alpine x Beetal goat, Singh et al. (2004a) of 450 days for Black Bengal goat and Amit-Kumar et al. (2011) of 536.04 days for Black Bengal and Beetal x Black Bengal does. The overall weight at first kidding was observed to $13.22 \mathrm{~kg}$ in the present study. This result was comparable with the findings reported by Hossain et al. (2004) of $15.41 \mathrm{~kg}$ and Singh and Rai (2004b) of $15.3 \mathrm{~kg}$ and Chowdhury et al. (2002) of 13.50kg for Black Bengal goat. The subsequent age and weight had the similar pattern, as in first kidding.

Table 1. Overall reproductive performance of Black Bengal goats

\begin{tabular}{llll}
\hline Traits & No. of records & Least-squares means with standard error & CV (\%) \\
\hline Age at first kidding(days) & 295 & $465.6 \pm 12.45$ & 34.64 \\
Weight at $1^{\text {st }}$ kidding & 269 & $13.22 \pm 0.24$ & 14.65 \\
Gestation & 406 & $145.34 \pm 0.32$ & 2.90 \\
length (days) & & $123.84 \pm 1.85$ & 42.97 \\
Pos-partum heat(days) & 160 & $302.5 \pm 4.55$ & 23.90 \\
Kidding interval(days) & 137 & $1.61 \pm 0.02$ & 32.73 \\
Litter size at birth & 429 & $1.66 \pm 0.04$ & 35.64 \\
Litter weight at birth & 429 & &
\end{tabular}

The overall mean for gestation length in the present study was 145.34 days almost similar with those observed by Faruque et al. (2010) of 143.33 days and Roy et al. (2007) of 144.08 days for Black Bengal goat.

The overall mean for Pos-partum heat(days) in the present study was 123.84 days. Lower values reported by Hossain et al. (2004) of 77.29 days and Chowdhury et al. (2002) 37.0 days for Black Bengal goat and higher values reported by Singh and Roy (2003) of 213.25 days for Jamnapari goats.

The overall mean for kidding interval in the present study was 302.50 days which was almost similar with those observed by Singh et al. (2004b) of 294.92 days for Black Bengal goat, Roy et al. (2007) of 328.49 days for Saanen goats and Ribas et al. (2003) of 346.0 days for Saanen goats. 
The overall litter size at birth was observed to 1.61 in the present study. This result was comparable with the findings reported by Hossain et al. (2004), Amin et al. (2001), Hoque et al. (2002) for Black Bengal goats and Hamed et al. (2009) for Zarabi goats in Egypt.

The overall litter weight at birth was observed to $1.66 \mathrm{~kg}$ in the present study. This result was lower with the findings reported by Kataktalware et al. (2004) of 3.90kg for Alpine x Beetal goats and Laczo et al. (2006) of $3.40 \mathrm{~kg}$ for Boer goat.

\subsection{Effect of Fixed Factors}

\subsubsection{Age at First Kidding}

The age at $1^{\text {st }}$ kidding in different flocks were almost similar and calculated to be $1^{\text {st }}, 2^{\text {nd }}$ and $3^{\text {rd }}$ parities (months) $14.95 \pm 0.43,15.75 \pm 0.56,16.25 \pm 0.95$ at BAU, $16.54 \pm 0.29,15.90 \pm 0.27,14.96 \pm 0.60$ at Madhupur $15.69 \pm 0.23$, $13.63 \pm 0.42$ and $15.43 \pm 0.57$ at Dimla (Figure 1).

\subsubsection{Weight at First Kidding}

The weights of dam at first kidding were almost similar in different flocks and calculated to be $1^{\text {st }}, 2^{\text {nd }}$ and $3^{\text {rd }}$ parities (months) $10.36 \pm 0.44,10.81 \pm 0.51,10.25 \pm 0.84$ at BAU, $9.46 \pm 0.41,7.33 \pm 0.44,6.35 \pm 0.64$ at Madhupur and $10.84 \pm 0.14,9.98 \pm 0.18$ and $10.56 \pm 0.34$ at Dimla (Figure 2).

Least-squares means and standard errors for gestation length (days), litter size at birth, litter weight at birth (kg), post-partum heat (days) and kidding interval (days) are presented in Table 2.

Table 2. Effect of different factors on the reproductive performance of goats

\begin{tabular}{|c|c|c|c|c|c|c|c|c|c|c|}
\hline \multirow{2}{*}{ Factor } & \multicolumn{2}{|c|}{ Litter size } & \multicolumn{2}{|c|}{ Litter weight(kg) } & \multicolumn{2}{|c|}{$\begin{array}{l}\text { Gestation } \\
\text { length(days) }\end{array}$} & \multicolumn{2}{|c|}{$\begin{array}{l}\text { Post-partum } \\
\text { (days) }\end{array}$} & \multicolumn{2}{|c|}{$\begin{array}{l}\text { Kidding } \\
\text { Interval(days) }\end{array}$} \\
\hline & $\mathrm{n}$ & $\mathrm{LSM} \pm \mathrm{SE}$ & $\mathrm{n}$ & $\mathrm{LSM} \pm \mathrm{SE}$ & $\mathrm{n}$ & $\mathrm{LSM} \pm \mathrm{SE}$ & $\mathrm{n}$ & $\mathrm{LSM} \pm \mathrm{SE}$ & $\mathrm{n}$ & $\mathrm{LSM} \pm \mathrm{SE}$ \\
\hline Flock & & $*$ & & $*$ & & NS & & $*$ & & $*$ \\
\hline BAU & 132 & $1.53^{\mathrm{a}} \pm 0.06$ & 130 & $2.09^{\mathrm{a}} \pm 0.04$ & 108 & $144.02 \pm 0.9$ & 65 & $120.4^{\mathrm{b}} \pm 10.4$ & 52 & $307.8^{\mathrm{b}} \pm 15.2$ \\
\hline Madhupur & 111 & $1.45^{\mathrm{b}} \pm 0.09$ & 113 & $1.74^{\mathrm{b}} \pm 0.06$ & 112 & $145.34 \pm 0.5$ & 26 & $130.01^{\mathrm{b}} \pm 4.9$ & 25 & $318.6^{\mathrm{b}} \pm 18.3$ \\
\hline Dimla & 186 & $1.40^{\mathrm{b}} \pm 0.2$ & 186 & $1.48^{\mathrm{b}} \pm 0.02$ & 186 & $147.34 \pm 0.4$ & 60 & $150.1^{\mathrm{a}} \pm 10.2$ & 60 & $330.5^{\mathrm{a}} \pm 13.2$ \\
\hline Generation & & $*$ & & $*$ & & NS & & $*$ & & $*$ \\
\hline 1 & 105 & $1.25^{\mathrm{b}} \pm 0.05$ & 105 & $1.80^{\mathrm{a}} \pm 0.03$ & 112 & $145.32 \pm 0.5$ & 66 & $125^{\mathrm{a}} \pm 5.1$ & 30 & $306.15^{\mathrm{a}} \pm 15.2$ \\
\hline 2 & 175 & $1.58^{\mathrm{a}} \pm 0.07$ & 175 & $2.26^{\mathrm{b}} \pm 0.05$ & 180 & $144.20 \pm 0.5$ & 55 & $115^{\mathrm{a}} \pm 7.5$ & 60 & $295.15^{\mathrm{b}} \pm 15.2$ \\
\hline 3 & 149 & $1.62^{\mathrm{a}} \pm 0.06$ & 149 & $2.40^{\mathrm{b}} \pm 0.03$ & 114 & $144.00 \pm 0.5$ & 30 & $105^{\mathrm{b}} \pm 2.45$ & 47 & $294.00^{\mathrm{b}} \pm 15.2$ \\
\hline Parity & & $* *$ & & $* *$ & & NS & & $*$ & & $*$ \\
\hline 1 & 132 & $1.33^{\mathrm{c}} \pm 0.04$ & 130 & $1.27^{\mathrm{c}} \pm 0.08$ & 108 & $144 \pm 0.53$ & 65 & $120.5^{\mathrm{a}} \pm 7.3$ & 52 & --- \\
\hline 2 & 111 & $1.54^{\mathrm{b}} \pm 0.07$ & 113 & $1.72^{\mathrm{b}} \pm 0.13$ & 112 & $144 \pm 0.45$ & 26 & $112.21^{\mathrm{b}} \pm 5.2$ & 25 & $240.6^{\mathrm{b}} \pm 6.3$ \\
\hline 3 & 186 & $1.77^{\mathrm{a}} \pm 0.09$ & 186 & $2.21^{\mathrm{a}} \pm 0.17$ & 186 & $143 \pm 0.39$ & 60 & $90.5^{\mathrm{b}} \pm 3.8$ & 60 & $285.9^{\mathrm{a}} \pm 10.3$ \\
\hline Season & & NS & & $*$ & & NS & & $*$ & & $*$ \\
\hline Winter & 132 & $1.54 \pm 0.10$ & 130 & $1.23^{\mathrm{a}} \pm 0.17$ & 108 & $144.55 \pm 1.12$ & 65 & $155.3^{\mathrm{a}} \pm 12.4$ & 52 & $288.6^{\mathrm{a}} \pm 11.3$ \\
\hline Summer & 111 & $1.47 \pm 0.08$ & 113 & $1.10^{\mathrm{ab}} \pm 0.13$ & 112 & $144.80 \pm 1.12$ & 26 & $135.05^{\mathrm{b}} \pm 5.8$ & 25 & $260.4^{\mathrm{b}} \pm 10.4$ \\
\hline Rainy & 186 & $1.52 \pm 0.14$ & 186 & $0.84 \pm 0.12^{b}$ & 186 & $143.23 \pm 1.90$ & 60 & $120.1^{\mathrm{b}} \pm 10.3$ & 60 & $270.3^{\mathrm{b}} \pm 10.9$ \\
\hline
\end{tabular}

Means with different superscripts within each column and trait differ significantly. NS, Not significant; *, $(\mathrm{P}<0.05) ; * *,(\mathrm{P}<0.01)$. 


\subsubsection{Post-Partum Heat Period}

The post-partum heat period (days) varied significantly $(\mathrm{p}<0.05)$ within the flocks, generation, parity and season and having the lowest period for BAU flock (120.4 \pm 10.4$)$, generation $3(105 \pm 2.45)$, parity $3(90.5 \pm 3.8)$, rainy season $(120.1 \pm 10.3)$ and highest for Dimla flock $(150.1 \pm 10.2)$, generation $1(125 \pm 5.1)$, parity $1(120.5 \pm 7.3)$ and winter season (155.3 \pm 12.4$)$ (Table 2).

\subsubsection{Kidding Interval}

The period between two consecutive kiddings were analysed for each individual animal. The result of least-squares analysis showed that the flocks, generation, parity and season for kidding interval are significant $(\mathrm{p}<0.05)$ and had the similar trend as in post-partum heat period (days) having the lowest value for BAU flock (307.8 \pm 15.2 ), for generation 3 (294.00 15.2$)$. The lowest value for kidding interval was at parity $2(240.6 \pm 6.3)$ and summer season (260.4 \pm 10.4$)$. The highest value for kidding interval was at Dimla flock (330.5 \pm 13.2$)$, generation 1 (306.15 \pm 15.2$)$, parity $1(285.90 \pm 10.3)$ and winter season $(288.6 \pm 11.3)$ (Table 4.13). The pos-partum heat (days) and kidding interval (days) was found (Table 2) significant $(\mathrm{P}<0.05)$ in this study. In case of kidding interval same result was found by (Wilson et al., 1989), which ranged from 238-265days. Higher value 349.41 to 362 has reported by (Lobo et al., 2005) than this study. The increase in productivity with parity indicates improvement of reproductive traits as does reach maturity.

\subsubsection{Litter Size and Litter Weight}

Litter size and litter weight were analysed from the individual kidding records for each animal in different flocks, generations, parities and seasons (Table 2). The analysis of variance for litter size and litter weight at different flocks $(p<0.05)$, generation $(p<0.05)$, parity $(p<0.01)$ are significant. The least-squares analyses of variance for liter size and litter weight are presented in Table 2 . The highest litter size and litter weight were observed at BAU flock $(1.53 \pm 0.06$ and $2.09 \pm 0.04 \mathrm{~kg})$ and lowest at Dimla flock $(1.40 \pm 0.2$ and $1.48 \pm 0.02 \mathrm{~kg})$. Trends of increasing the litter size and litter weight are observed with the advancement of generation and parities (Table 2). Similar results was reported by Faruque et al. (2010) for litter size at birth of (1.33 to 1.77) and litter weight at birth (1.27 to $2.21 \mathrm{~kg}$ ) increased significantly $(\mathrm{P}<0.01)$ as parity progressed. Hussain et al. (2004) noticed that among the four parities, kid's birth weight was lowest in 1st parity does compared to $2 \mathrm{nd}$, 3rd and 4th parity. This may be due to improved efficiency of reproduction as the doe matures. The increase in litter size was reported to continue to the fourth parity and six (Fogarty et al., 2000) years of age and declined thereafter. The increase in litter size with advance in age and parity is the result of increased ovulation rate, uterine capacity and other maternal traits affecting the reproductive efficiency (Fahmy, 1990). Parity of doe significantly influenced litter size at birth, litter weight $(\mathrm{kg})$ at birth and, first kidding being the smallest which was in agreement with the findings of Chowdhury et al. (2002), Marai et al. (2002), Hoque et al. (2002), Song (2003) and Hamed et al. (2009).

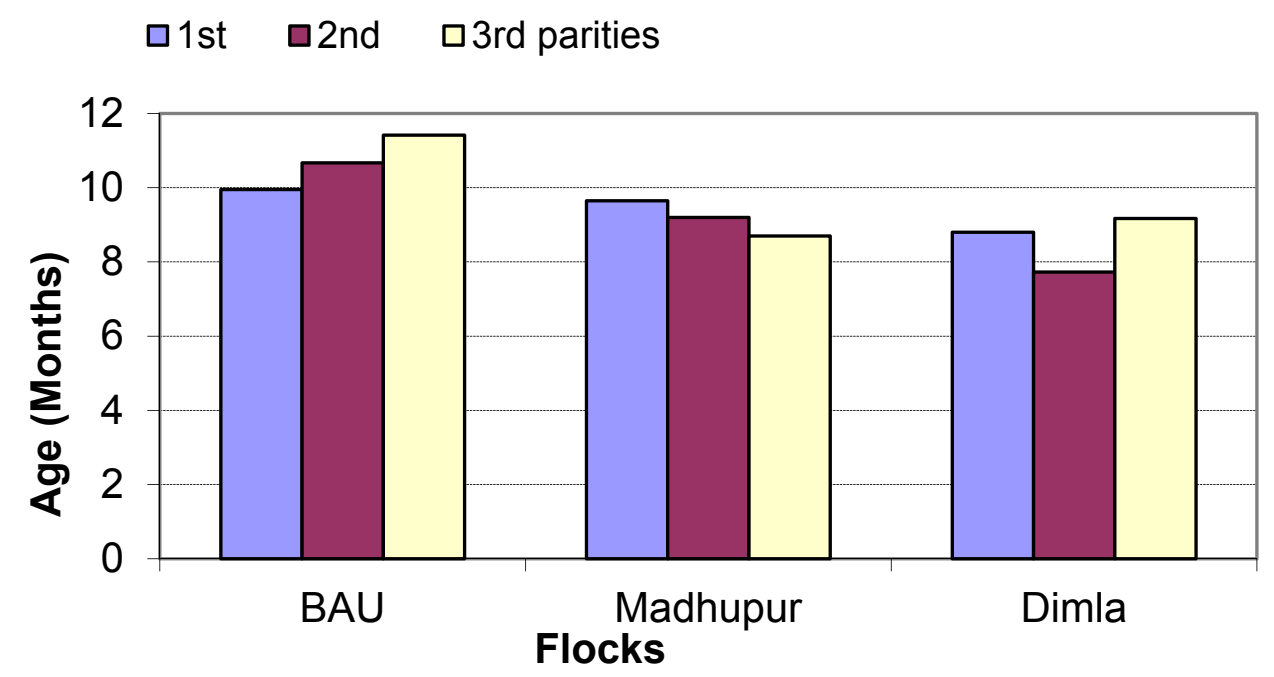

Figure 1. Age of dams in different partities 


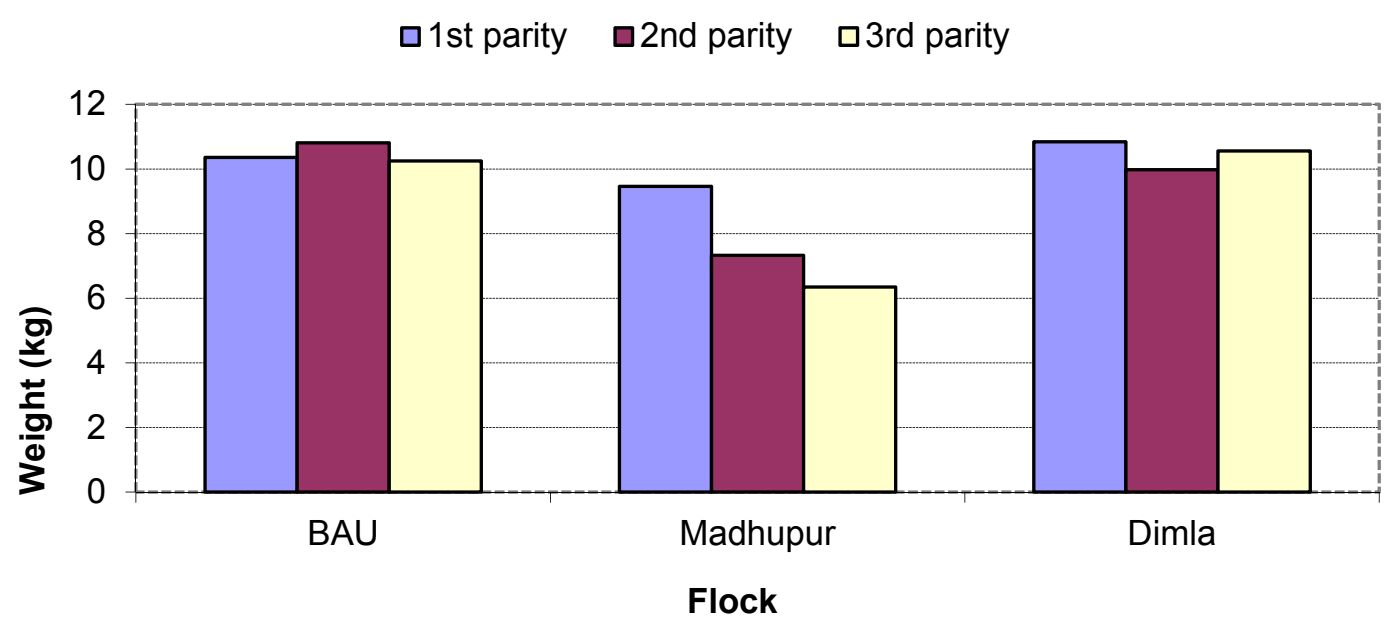

Figure 2. Weight of dams in different parities

\subsubsection{Gestation Length}

Gestation length of each goat in different flock, generation and parities was analysed. The lowest gestation length was obtained at flock BAU (144.02 \pm 0.9 days), at generation 2 and 3 (144.20 \pm 0.5 days) at 3rd parity $143 \pm 0.39$ days and at rainy season 143.23 \pm 1.90 days (Figure 4.11). No significant difference was found for this trait (Table 4.13). For gestation length flock effect and generation effect was not significant. Similar results was reported by Faruque et al. (2010) for generation one143.00 days and generation two 141.25 days. The effect of parity on gestation length was found to be non-significant in the present study. Almost similar findings for gestation length were reported by Chowdhury et al. (2002), Kataktalware et al. (2004) and Hossain et al. (2004), Roy et al. (2007), Chun-Yan Zhang et al. (2009), in different goats. The factors which are responsible for the variation of gestation length and kidding interval may be equally considered for the variation of post-partum heat in different regions, parities and seasons (Husain, 2000).

The present study indicated that season of kidding had no significant influence on the Litter size and gestation length. Litter weight, post-partum heat (days) and kidding interval in Black Bengal goats were significant $(\mathrm{P}<0.05)$ in the present study which was supported by Browning et al. (2011) and Gbangboche et al. (2006) and Hamed et al. (2009). It is observed that there is minimal rainfall during the winter which intern responsible for green grasses on the field, is only the available means for feeding the goats. This period is mainly covered with the late part of winter and early part of summer and is considered as the most critical time for grazing the animals on the field. Tree leaves are also very limited for growth during this period.

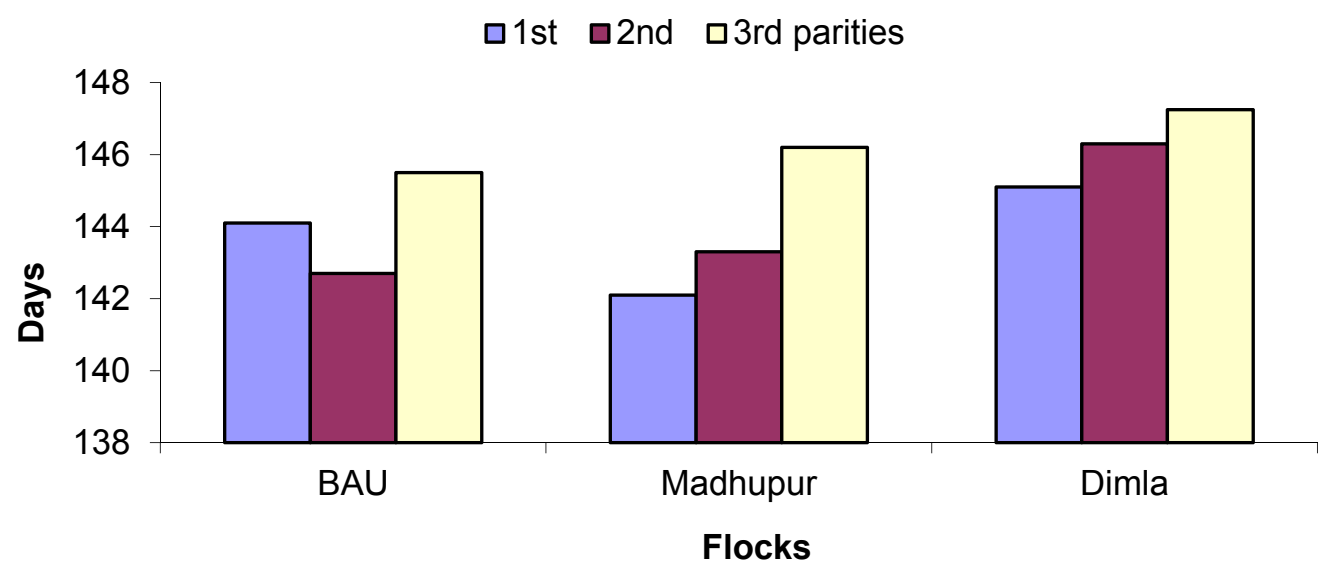

Figure 3. Gestation lengths of does in different parities 


\subsection{Variance Components and Heritability}

Estimates of additive genetic variance $\left(\sigma^{2} a\right)$, residual variance $\left(\sigma^{2} e\right)$, phenotypic variance $\left(\sigma^{2} p\right)$ and heritability $\left(h^{2}\right)$ of age at first kidding, weight at first kidding, litter size at birth, litter weight at birth, gestation length, post-partum heat and kidding interval and repeatability of litter size at birth and kidding interval of Black Bengal kids are in Table 4.14 which are comparable to those results reported by Ribeiro et al. (2000), Lobo et al. (2005), Menendez et al. (2003), Rao and Notter (2000), Neopane (2000), Ricordeau (1991), Bagnicka (2007), Sarmento et al. (2003) and Vatankhah et al. (2008). It appears from the table that heritability estimates of those traits are rather low, and reflect the generally small genetic variance for the reproductive traits. Low heritability of reproductive traits is probably due to greater proportional influence of environmental effects as well as little genetic variability for fertility, litter size and other reproductive traits.

Table 3. Estimates of additive genetic variance $\left(\sigma^{2} a\right)$, residual variance $\left(\sigma^{2} e\right)$, phenotypic variance $\left(\sigma^{2} p\right)$ and heritability $\left(\mathrm{h}^{2}\right)$ of age at first kidding, weight at first kidding, litter size at birth, litter weight at birth, gestation length, post-partum heat and kidding interval and repeatability of litter size at birth and kidding interval of Black Bengal kids

\begin{tabular}{lllllc}
\hline Traits & $\sigma^{2} \mathrm{a}$ & $\sigma^{2} \mathrm{e}$ & $\sigma^{2} \mathrm{p}$ & $\mathrm{h}^{2}$ & $\mathrm{r}_{\mathrm{p}}$ \\
\hline Age at first kidding & 1.383 & 5.206 & 6.589 & $0.21 \pm 0.11$ & \\
Weight at first kidding & 1.53 & 6.991 & 8.521 & $0.18 \pm 0.10$ & \\
Litter size at birth & 0.026 & 0.159 & 0.185 & $0.14 \pm 0.12$ & $0.16 \pm 0.12$ \\
Litter weight at birth & 0.045 & 0.331 & 0.376 & $0.12 \pm 0.08$ & \\
Gestation length & 1.668 & 5.191 & 7.582 & $0.22 \pm 0.11$ & \\
Post-partum heat & 0.876 & 2.778 & 3.654 & $0.24 \pm 0.14$ & \\
Kidding interval & 0.974 & 4.761 & 5.735 & $0.17 \pm 0.11$ & $0.045 \pm 0.04$ \\
\hline
\end{tabular}

\subsection{Predicted Breeding Value and Ranking of Bucks}

Breeding values as calculated by BLUP technique for reproductive performance were ranked then according to their genetic worth. On the basis of PBV of litter size at birth, litter weight at birth, age at first kidding, weight at first kidding, gestation length, post-partum heat period and kidding interval were estimated and according to value prioritized bucks were selected (Figure 4). Column of the entire figure show the predicted breeding value for each individual. The highest breeding value of reproductive traits was found in the progeny of Buck No. 32, followed by Buck No. 52, 54, 81 and 87 . The lowest breeding value of reproductive traits was found from the progeny of Buck No. 3 followed by Buck No. 11 and 4 (Figure 4).

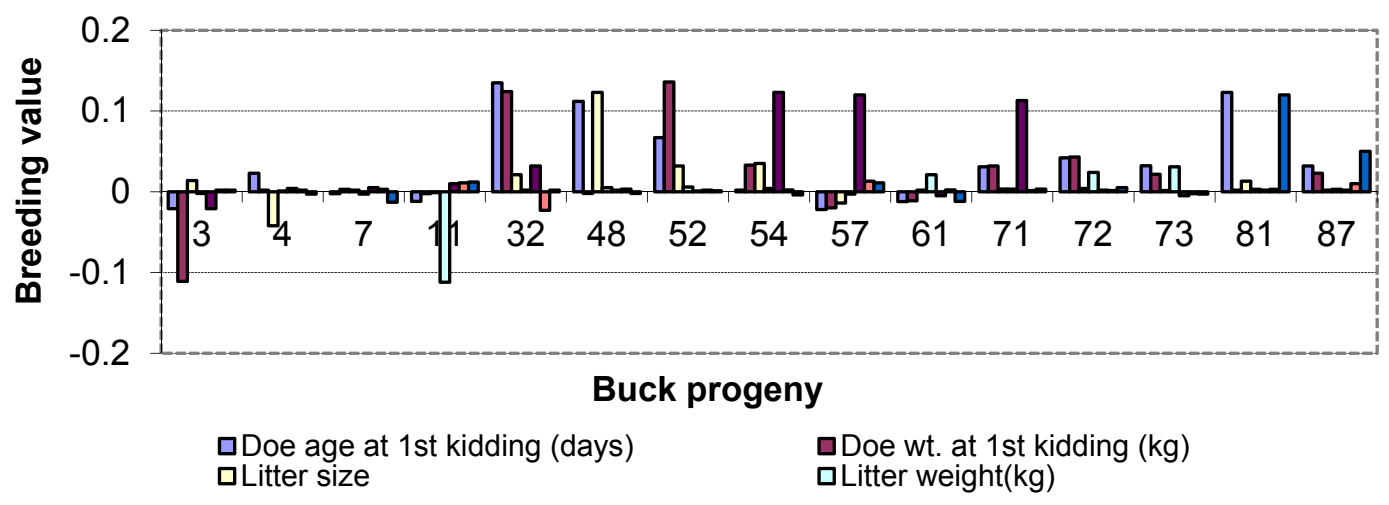

Figure 4. Predicted breeding value of different reproductive traits of different bucks' progeny 


\section{Conclusion}

Estimates of heritability for reproductive traits in this study were quite low and hence presence of large environmental variances, indicating that possibility of selection based on doe's own performance to improve these reproductive traits would take a long time and improvement in these traits through selection may be limited. So, Bucks may be selected through progeny testing maintaining the appropriate reproductive management program addressing most important individual traits which are directly involved for increasing lifetime productivity. References

Amin, M. R., Husain, S. S., \& Islam, A. B. M. M. (2001). Reproductive peculiarities and litter weight in different genetic groups of Black Bengal does. Asian-Aust. J. Anim. Sci., 14, 297-301.

Amit-Kumar, Singh, L. B., Dhirendra, K., Maroof, A. (2011). Factors affecting reproductive traits in Black Bengal and Beetal x Black Bengal crosses. Ind. J. Small Ruminants, 17(2), 225-226.

Bagnicka, E., Wallin, E., Łukaszewicz, M., \& Adnøy, T. (2007). Heritability for reproduction traits in Polish and Norwegian populations of dairy goat. Small Rumin. Res., 68, 256-262. http://dx.doi.org/10.1016/j.smallrumres.2005.09.033

Bradford, G. E. (1985). Selection for litter size. In R. B. Land, \& D. W. Robinson (Eds.), Genetics of Reproduction in Sheep (pp. 3-18). London: Butterworths.

Bradford, G. E., Quirke, J. F., Sitorus, P., Inounu, I., Tiesnamurti, B., Bell, F.L., ... Torell, D. T. (1986). Reproduction in Javanese sheep: evidence for a gene with large effect on ovulation rate and litter size. J. Anim. Sci., 63, 418-431.

Browning, R. J., Leite-Browning, M. L., \& Byars, M. J. (2011). Reproductive and health traits among Boer, Kiko, and Spanish meat goat does under humid, subtropical pasture conditions of the southeastern United States. $J$. Anim.Sci., 89(3), 648-660. http://dx.doi.org/10.2527/jas.2010-2930

Devendra, C., \& Burns, M. (1970). Goat production in the Tropics. Tech. Commun. No. 19, Comm. Bur. Anim. Breed. Genet., CAB, Farnham Royal, Bucks, England.

Devendra, C., \& Burns, M. (1983). Goat Production in the Tropics. Commonwealth Agric. Bureaux, Farnham Royal, Bucks, U.K.

Dhara, K. C., Ray, N., Roy, S., Samanta, A. K., \& Senapati, P. K. (2008). Improvement of reproductive performances of Black Bengal goat through selection under field condition. J. Anim. Vet. Advan., 7(5), 599-603.

Dickerson, G. E. (1978). Animal size and efficiency: Basic concepts. Anim. Prod., 27, 367-379. http://dx.doi.org/10.1017/S0003356100036278

Fahmy, H. H. (1990). The accumulative effect of Finnsheep breeding in crossbreeding schemes: ewe productivity under an accelerated lambing system. Can. J. Anim. Sci., 70, 967-971. http://dx.doi.org/10.4141/cjas90-117

Falconer, D. S. (1989). Introduction to Quantitative Genetics. Essex, U.K.: Longman Press.

Faruque, S., Chowdhury, S. A., Siddiquee, N. U., \& Afroz, M. A. (2010). Performance and genetic parameters of economically important traits of Black Bengal goat. Journal Bangladesh Agril. Univ., 8(1), 67-78.

Fogarty, N. M., Cummins, L., Stafford, J., Gaunt, G., \& Banks, R. G. (2000). Opportunities for improvements of maternal performance in the lamb industry. Proc. $9^{\text {th }}$ Congress of the Asian-Australasian Association of Animal Prod. Societies and 23 Biennial of the Australian Society of Animal Prod. July 3-7, University of New South Wales, Sydney, Australia, pp. 309-311.

Greyling, J. P. C. (1988). Certain aspects of reproductive physiology in the Boer goat doe. D.Sc. thesis, University of Stellenbosch, South Africa. http://dx.doi.org/10.1016/S0921-4488(99)00161-3

Greyling, J. P. C. (2000). Reproduction traits in the Boer goat doe. Small Rumin. Res., 36, 171-177.

Groeneveld, E. (2003). VCE4. User's Guide and Reference Manual, Version, 5.1. Institute of animal Husbandry and Animal Behaviour, Federal Agricultural Research Centre (FAL), Neustadt. Germany.

Hamed, A., Mabrouk, M. M., Shaat, I., Bata, S. (2009). Estimation of genetic parameters and some nongenetic factors for litter size at birth and weaning and milk yield traits in Zaraibi goats. Egyptian J. Sheep Goat Sci., 4, $55-64$.

Hoque, M. A., Amin, M. R., \& Baik, D. H. (2002). Genetic and non-genetic causes of variation in gestation length, litter size and litter weight in goats. Asian-Aust. J. Anim. Sci., 15, 772-76. 
Hossain, S. M. J., Sultana, N., Alam, M. R., \& Rashid, M. M. (2004). Reproductive performance of Black Bengal goat under semi-intensive management. J. Biol. Sci., 4, 537-41. http://dx.doi.org/10.3923/jbs.2004.537.541

Husain, S. S., Horst, P., \& Islam, A. B. M. M. (1996). Study on the growth performance of Black Bengal goats in different periods. Small Rumin. Res., 21, 165-171. http://dx.doi.org/10.1016/0921-4488(95)00832-2

Kataktalware, M. A., Charan, S., \& Gupta, A. K. (2004). First lactation reproductive performance of crossbred dairy goats under stall fed conditions. Ind. J. Small Ruminants, 10(2), 104-107.

Laczo, E., Pajor, F., \& Poti, P. (2007). Goat place in the sustainable agriculture: compare some growth traits of meat type and dual-purpose type goats in Hungary. Cere.Res.Commun., 35(2), 701-704. http://dx.doi.org/10.1556/CRC.35.2007.2.134

Lobo, R. N. B., \& Silva, F. L.-R. (2005). Genetic parameters for economics traits in Saanen and Anglo-Nubian goats. Rev.Cien. Agro., 36(1), 104-110.

Marai, I. F. M., Abou-Fandoud, E. I., Daader, A. H., \& Abu-Ella, A. A. (2002). Reproductive doe traits of the Nubian (Zaraibi) goats in Egypt. Small Rumin. Res., 46, 201-205. http://dx.doi.org/10.1016/S0921-4488(02)00195-5

Menendez, B. A., Alexandre, G., Mandonnet, N., Naves, M., \& Aumont, G. (2003). Direct genetic and maternal effects affecting litter size, birth weight and pre-weaning losses in Creole goats of Guadeloupe. Anim. Sci., 77(3), 363-369.

Morand-Fehr, P. (1981). Growth. In C. Gall (Ed.), Goat Production. Academic Press Inc. (London) Ltd. 24-28 Oval Road, London NW1 7DX.

Mourad, M. (1996). Estimation of repeatability of litter size of Common African goats and cross with Alpine in Rwanda. Small Rumin. Res., 19, 263-266. http://dx.doi.org/10.1016/0921-4488(95)00742-3

Neopane, S. P. (2000). Selection for improvement of the productivity of Hill goats in Nepal. Proceedings of the $7^{\text {th }}$ International Conference on Goats (pp. 206-208). Organized by International Goat Association, France.

Piper, L. R., \& Bindon, B. M. (1982). Genetic segregation for fecundity in Booroola Merino sheep. In R.A. Barton, \& D.W. Robinson (Eds.), Genetics of Reproduction in Sheep (pp. 159-168). Butterworths, London.

Rao, S., \& Notter, D. R. (2000). Genetic analysis of litter size in Targhee, Suffolk, and Polypay sheep. J. Anim. Sci., $78,2113-2120$.

Ribas, M., Gutierrez, M., \& Hernandez, F. (2003). Reproductive performance and the study of culled animals in four dairy goat breeds in Cuba. Cub. J. Agr. Sci., 37(1), 11-19.

Ribeiro, A. C., Lui, J. F., Queiroz, S. A., Ribeiro, S. D. A., \& Resende, K. T. (2002). Genetic and environmental effects on the Age at First Kidding and Kidding Interval in a Saanen goat herd. Ars Vet., 16(3), 192-197.

Ricordeau, G., Poujardieu, B., \& Bouillon, J. (1991). Genetic parameters of growth in young Saanen female goats in a testing station. Annls. G'en. S'el. Anim., 4, 477-480.

Riera, S. (1982). Reproductive efficiency and management in goats. Proc. 3rd Inter. Conf. on Goat Prod. and Disease (pp. 162-174). Tuscon, Arizona, USA.

Roy, N., Ishwar, A. K., \& Singh, S. K. (2007). Reproductive performance of Black Bengal goats - a note. Ind. J. Small Ruminants., 13(1), 84-85.

Safari, E., Fogarty, N. M., \& Gilmour, A. R. (2005). A review of genetic parameter estimates for wool, growth, meat and reproduction traits in sheep. Livest. Prod. Sci., 92, 271-289. http://dx.doi.org/10.1016/j.livprodsci.2004.09.003

Sarmento, J. L. R., Pimenta Filho, E. C., Ribeiro, M. N., Araujo, C. V., Breda, F. C, Pires, A.V., ,.. Torres, R. A. (2003). Genetic and environmental factors affecting the kidding interval of dairy goats in the semi-arid northeastern. Rev. Brasi. Zoot., 32(4), 875-879. http://dx.doi.org/10.1590/S1516-35982003000400012

Shelton, M. (1978). Reproduction and breeding of goats. J. Dairy Sci., 61, 994-1010. http://dx.doi.org/10.3168/jds.S0022-0302(78)83680-7

Singh, D. K., Singh, D. K., Singh, L. B., \& Gajbhyie, S. (2004b). Reproductive performance of Black Bengal goats under semi-intensive system. J. Res. Birsa Agri. Uni., 16(1), 147-151.

Singh, M. K., \& Rai, B. (2004b). Goat production status in the eastern region of India. Live. Inter., 8(12), 9-23. 
Singh, M. K., Roy, R. (2003). Effect of nongenetic factors on reproduction traits in Jamunapari goats under semiintensive management. Ind. J. Small Ruminants, 9(2), 112-115.

Snowder, G. D. (2008). Genetic improvement of overall reproductive success in sheep: A review. Asociación Latinoamericana de Producción Animal, 16(1), 32-40. Retrieved from www.alpa.org.ve/ojs.index/php

Song H. B., Jo, I. H., \& Sol, H. S. (2006). Reproductive performance of Korean native goats under natural and intensive conditions. Small Rumin. Res., 65, 284-287.

Song, H. B. (2003). Reproduction Traits in the Korean Native Goat Doe. Korean J. Anim. Reprod, 27, 289-97. http://dx.doi.org/10.1016/j.smallrumres.2005.08.001

Van der Westhuysen, J. M. (1980). Reproductive efficiency of Angoras in South Africa. S. Afr. J. Anim. Sci., 10, 99-101.

Vatankhah, M., \& Salehi, S. A. (2008). Genetic and non-genetic factors affecting Lori Bakhtiari ewe body weight and its relationship with productivity. Small Rumin. Res., 94, 98-102. http://dx.doi.org/10.1016/j.smallrumres.2010.07.006

Wang, C. T., \& Dickerson, G. E. (1991). Simulated effects of reproductive performance on life-cycle efficiency of lamb and wool production at three lambing intervals. J. Anim. Sci., 69, 4338-4347.

Wilson, R. T. (1989). Reproduction performance of African indigenous small ruminants under various management systems. Anim. Reprod. Sci., 20, 265-286. http://dx.doi.org/10.1016/0378-4320(89)90075-4

Zhang, C. Y., Chen, S. L., Li, X., Xu, D. Q., Zhang, Y., \& Yang, L. G. (2009). Genetic and phenotypic parameter estimates for reproduction traits in the Boer dam. Livestock Science, 125(1), 60-65. http://dx.doi.org/10.1016/j.livsci.2009.03.002

\section{Copyrights}

Copyright for this article is retained by the author(s), with first publication rights granted to the journal.

This is an open-access article distributed under the terms and conditions of the Creative Commons Attribution license (http://creativecommons.org/licenses/by/3.0/). 